\title{
Diverse population trajectories among coexisting species of subarctic forest moths
}

\author{
Mikhail V. Kozlov $\cdot$ Mark D. Hunter • \\ Seppo Koponen · Jari Kouki • Pekka Niemelä • \\ Peter W. Price
}

Received: 19 May 2008/Accepted: 6 October 2009/Published online: 12 December 2009

(C) The Society of Population Ecology and Springer 2009

\begin{abstract}
Records of 232 moth species spanning 26 years (total catch of ca. 230,000 specimens), obtained by continuous light-trapping in Kevo, northernmost subarctic Finland, were used to examine the hypothesis that lifehistory traits and taxonomic position contribute to both relative abundance and temporal variability of Lepidoptera. Species with detritophagous or moss-feeding larvae, species hibernating in the larval stage, and species pupating during the first half of the growing season were over-represented among 42 species classified as abundant during the entire sampling period. The coefficients of variation in annual catches of species hibernating as eggs averaged 1.7
\end{abstract}

\author{
M. V. Kozlov ( $₫)$ \\ Section of Ecology, University of Turku, \\ 20014 Turku, Finland \\ e-mail: mikoz@utu.fi
}

M. D. Hunter

Department of Ecology and Evolutionary Biology,

University of Michigan, Ann Arbor, MI 48109-1048, USA

M. D. Hunter

School of Natural Resources and Environment,

University of Michigan, Ann Arbor, MI 48109-1048, USA

S. Koponen

Zoological Museum, University of Turku, 20014 Turku, Finland

J. Kouki

Faculty of Forest Sciences, University of Joensuu,

80101 Joensuu, Finland

\section{P. Niemelä}

Section of Biodiversity and Environmental Science,

University of Turku, 20014 Turku, Finland

P. W. Price

Department of Biological Sciences, Northern Arizona

University, Flagstaff, AZ 86011-5640, USA times higher than those of species hibernating as larvae or pupae. Time-series analysis demonstrated that periodicity in fluctuations of annual catches is generally independent of life-history traits and taxonomic affinities of the species. Moreover, closely related species with similar life-history traits often show different population dynamics, undermining the phylogenetic constraints hypothesis. Species with the shortest (1 year) time lag in the action of negative feedback processes on population growth exhibit the largest magnitude of fluctuations. Our analyses revealed that only a few consistent patterns in the population dynamics of herbivorous moths can be deduced from life-history characteristics of the species. Moreover, the diversity of population behaviour in one moth assemblage challenges any conventional wisdom suggesting predictable patterns. Our results raise several questions about perceptions and paradigms in insect population dynamics and stress the need for research on detritivorous insect population dynamics, as well as the need for more assemblage-wide studies using common trapping methods to provide comparative data on related and unrelated species with different life-history traits.

Keywords Lepidoptera - Life histories . Population cycles $\cdot$ Rarity $\cdot$ Temporal variability

\section{Introduction}

Fluctuations in the densities or relative abundances of Lepidoptera are well known, and have received widespread attention in studies of insect population dynamics (Myers 1988; Hunter 1995a; Price 1997, 2003). However, in spite of several attempts to understand why some 1-2\% of species (Faeth 1987; Mason 1987) undergo outbreaks 
whereas the vast majority of Lepidoptera possess latent population dynamics (Myers 1988; Redfearn and Pimm 1988; Price 1990; Hunter 1991, 1995a; Ginzburg and Taneyhill 1994; Tammaru et al. 1995; Tammaru and Haukioja 1996; Ruohomäki et al. 2000; Haukioja 2005), no definitive links between life-history traits and eruptive population dynamics have yet been identified.

Several methodological issues may have contributed to the failure to detect life-history correlates of outbreaks, or to the inconsistency of results obtained in different studies. (1) The sample of 'outbreaking' species is biased towards species that compete with humans for food or fibre resources; this would generally exclude, for example, species feeding on forest herbs. (2) Although a change in abundance from 0.01 to 1 larvae per tree is an equivalent level of fluctuation to a change from 1,000 to 100,000 larvae per tree (Gaston and McArdle 1994), only the latter case is likely to be classified or reported as an outbreak. (3) The classification of species as 'outbreaking' or 'non-outbreaking' does not generally presume any ecologically sound criteria such as magnitude of density fluctuations. Only subjective characters are noted like "noticeable defoliation on a large scale, i.e., at least tens of square kilometres" (Hunter 1991, p. 276). (4) Raw density records are only rarely published, and therefore researchers trying to use data from different sources are faced with very different statistical approaches, with at least 23 published sampling estimators of variability (Gaston and McArdle 1994). Furthermore, surprisingly little is known about the periodicity of fluctuations in most insect populations (but see Turchin 1990), and the amount of reliable data on the characteristics of time series, such as the time lag in the action of density-dependent processes, or the degree of periodicity/stochasticity in density fluctuations (Hunter and Price 1998; Price and Hunter 2005; Redfern and Hunter 2005), remains too low for comparative study.

Time series of at least 30-40 steps are considered ideal for analyzing ecological factors that influence insect populations (Royama 1992), but shorter time series are commonly used (compare Turchin 1990; Berryman 1994) because longer-term data are rare (Hunter and Price 1998). The data that we use here, 26 years of continuous lighttrapping in the Kevo Subarctic Research Station of the University of Turku, represent a valuable resource in terms of both the longevity of the time series and its communitywide extent. Although light-trapping, like any other sampling method, does not represent equally the entire lepidopteran community, and counts can be affected by environmental conditions during the trapping period, it still has high comparative power for the analysis of many species simultaneously at a given location (Wolda et al. 1994). Furthermore, light-trapping allows monitoring of detritivores and moss-feeding species, for which fluctuations in relative abundance over long time periods have not been reported previously. Finally, the vital importance of community-wide data in studies of environmental change is appreciated by many researchers (Kremen 1992; New 1997), and we hope that moth trapping in Kevo will continue to yield long-term data. Here, we use original data from 26 years of light-trapping ${ }^{1}$ to examine the hypothesis that life-history traits and taxonomic position contribute to both relative abundance and temporal variability of Lepidoptera.

\section{Materials and methods}

Study site and sampling protocol

Moths were collected near the Kevo Subarctic Research Station in Lapland, northernmost Finland $\left(69^{\circ} 45^{\prime} \mathrm{N}, 27^{\circ} \mathrm{E}\right)$. The station is situated in the subarctic vegetation zone close to the border with the northern boreal zone. The characteristic vegetation types are forests dominated by mountain birch, Betula pubescens subsp. czerepanovii (Orlova) Hämet-Ahti, or Scots pine, Pinus sylvestris L., and extensive mires (for more details, see Kallio et al. 1969; Kallio 1975; Seppälä and Rastas 1980). Light traps were placed within an area of approximately $200 \times 300 \mathrm{~m}^{2}$ in the most common habitats surrounding the station: mixed pine-birch forest, birch and willow shrub, dwarf birch and sedge mire, and lake shore with birches (Linnaluoto and Koponen 1980). The elevation of trapping sites varied between 80 and $120 \mathrm{~m}$ a.s.l. Barren fells and birch woodlands, although frequent in the study area, were not sampled.

Light traps with blended-light lamps $(500 \mathrm{~W})$ were based on the type developed by Jalas (1960), and the moth container was equivalent to the type described by Karvonen et al. (1979). Traps were operated annually from 1972 during the entire plant growth season, generally from the last week of May to the last week of September. Note that between May 17 and July 24 the light period is continuous in Kevo ('white nights'). We used one trap in 1972, two traps in 1977, three traps in 1973, 1974, 1975, 1978, and 1979, and four traps in 1976 and from 1980 to 1997. Traps were generally switched on at 21:00 and off at 06:00, and containers were emptied once a week.

In order to identify species that were not easy to distinguish on the basis of external characters (most of the Nepticulidae and Coleophoridae), we attempted to pin all specimens and used genitalia preparations to confirm our determinations. A gap in the records for some of these species from 1980 to 1982 resulted from the partial loss of samples.

\footnotetext{
1 Although light-trapping has continued until recently, delays in specimen identification have restricted the current analysis to data from the first 26 years.
} 
Database

The total catch amounted to ca. 230,000 individuals of 232 species (ca. $95 \%$ of all species reported in the study site, cf. Linnaluoto and Koponen 1980). Taxonomy of moths follows Kullberg et al. (2002). Basic clades/grades of Lepidoptera (Fig. 1) are accepted according to Kristensen and Skalski (1998). Life-history characteristics (listed in Tables 1 and 2) were obtained from numerous specialist publications on Lepidoptera, including high-standard determination guides and comprehensive revisions of separate taxa, and from consultations with specialists (see "Acknowledgments").

Two points in our classification of life-history traits deserve special attention. First, only the species whose larvae started feeding in autumn and then continued feeding next spring were considered as hibernating at the larval stage. Second, the conventional borderline between early and late plant growing seasons is linked with leaf expansion and ageing. In the majority of woody plants and shrubs in our study area, leaf expansion starts in the last days of May to early June and generally ceases by late June to early July (Haukioja et al. 1978). Only species that completed larval development by this date were considered as pupating early in the season.

Data processing and analysis of relative abundance

Weekly species records from each trap were summed for the annual value, and then records of all traps were averaged for the annual mean. Hence, data reported here are mean numbers of individuals per species per year per trap. Note that we fully appreciate that our data reflect relative abundance of collected species, rather than population density in the strict sense. However, for the sake of brevity, we sometimes use the term 'density' in the following text (e.g., in the term 'density-dependent').

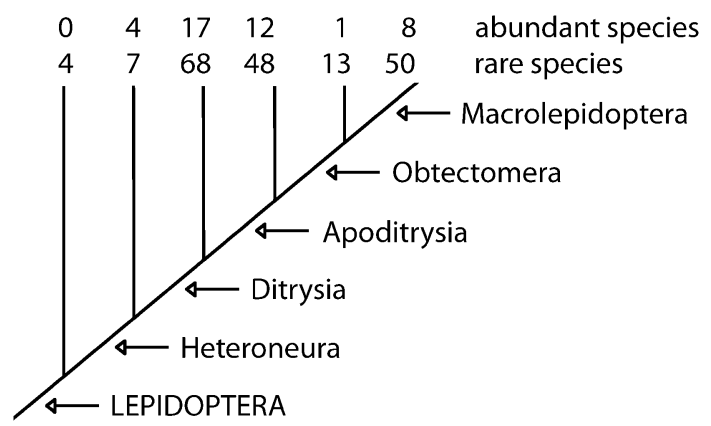

Fig. 1 Distribution of 42 abundant and 190 rare species collected at the Kevo Subarctic Research Institute, northern Finland, between 1972 and 1997, among the basic lineages of Lepidoptera. Phylogenetic arrangements are after Kristensen and Skalski (1998)
To identify biennial species within our samples, records from odd and even years were compared for each species separately with the non-parametric Kruskal-Wallis test (SAS NPAR1WAY procedure; SAS Institute 2009). For 15 species demonstrating biennial flight periodicity (differences between catches in even and odd years significant at probability level $P=0.01$ ) records of two consecutive years starting from 1972 were summed for further analysis, which resulted in 13 data points for these species compared with 26 data points for other (annual) species. This approach was preferred to separate analysis of catches in even and odd years, because in most of the biennial species, a 2-year life cycle is not inevitable, and populations flying in even and odd years are not completely separated. For species flying exclusively in even years, such as Xestia spp., the analysis of summed records produced the same result as the analysis of even-year data.

Various arbitrary criteria have been used to differentiate between 'rare' and 'abundant' species. For our purposes, we needed to distinguish between species that were trapped during a sufficient number of sampling years for analysis, even if in relatively low numbers each year, and species whose occurrence was a rare event, even if their numbers were occasionally quite high (for example, the arrival of large numbers of migrants during an exceptional year). Therefore, we classified as 'abundant' those species whose annual catches significantly exceeded 0.5 specimens/ trap $\times$ year (i.e., more than two specimens collected annually by four operating light traps) using a KruskalWallis test (SAS NPAR1WAY procedure). Those species whose catches did not exceed (at the significance level $P \leq 0.05)$ this arbitrary threshold value are hereafter called 'rare' species. Proportions of rare and abundant species classified according to their life-history characteristics (Table 1) or taxonomic position (Fig. 1) were compared by using the FREQ procedure in SAS (SAS Institute 2009).

The diamond back moth, Plutella xylostella (L.), which is known to migrate occasionally for very long distances (Lokki et al. 1978), was classified as a rare species in our analysis; it was abundant only during specific years (i.e., it had a highly skewed distribution of annual records), suggesting a migratory rather than a local origin of specimens.

For the abundant species, the magnitude of fluctuations was quantified by calculating the coefficient of variation (CV) of untransformed records which, according to Gaston and McArdle (1994), is the most appropriate statistic for this purpose.

Time-series analysis

Time-series models for each moth species were developed using the time-series forecasting procedure in SAS 9.2 (SAS Institute 2009), which generates maximum-likelihood 
Table 1 Summary of life-history traits and characteristics of density fluctuations of 'abundant' moths trapped at the Kevo Subarctic Research Institute, northern Finland, between 1972 and 1997

\begin{tabular}{|c|c|c|c|c|c|c|c|c|c|c|c|c|c|c|c|c|}
\hline \multirow[t]{2}{*}{ Family } & \multirow[t]{2}{*}{ Species } & \multicolumn{7}{|c|}{ Life-history characters } & \multirow{2}{*}{$\begin{array}{l}\text { Wing } \\
\text { span } \\
(\mathrm{mm})\end{array}$} & \multicolumn{3}{|c|}{$\begin{array}{l}\text { Annual catches, } \\
\text { individuals/trap }\end{array}$} & \multirow[t]{2}{*}{$\begin{array}{l}\mathrm{CV} \\
(\%)\end{array}$} & \multirow[t]{2}{*}{$\begin{array}{l}\text { Linear } \\
\text { trend }\end{array}$} & \multirow{2}{*}{$\begin{array}{l}\text { Time } \\
\text { lag } \\
\text { (years) }\end{array}$} & \multirow[t]{2}{*}{ Model $R^{2}$} \\
\hline & & FP & PT & HI & $\mathrm{LF}$ & FG & HP & SP & & Mean & Min & Max & & & & \\
\hline \multirow[t]{2}{*}{ Nepticulidae } & Stigmella lapponica & a & 1 & $\mathrm{p}$ & $\mathrm{p}$ & $\mathrm{m}$ & $\mathrm{w}$ & 1 & 6 & 2.00 & 0.0 & 10.0 & 128 & NS & No & NA \\
\hline & Ectoedemia weaveri & $\mathrm{b}$ & $\mathrm{e}$ & 1 & $\mathrm{p}$ & $\mathrm{m}$ & w & 1 & 7 & 10.85 & 0.0 & 41.2 & 69 & - & - & - \\
\hline \multirow[t]{2}{*}{ Incurvariidae } & Incurvaria vetulella & a & $?$ & $?$ & $?$ & $?$ & $?$ & $?$ & 15 & 1.20 & 0.0 & 6.8 & 125 & NS & 1 & 0.134 \\
\hline & Incurvaria circulella & $\mathrm{a}$ & $?$ & $?$ & $?$ & $?$ & $?$ & $?$ & 15 & 3.46 & 0.0 & 29.5 & 175 & NS & No & NA \\
\hline \multirow[t]{2}{*}{ Tineidae } & Monopis weaverella & $\mathrm{a}$ & $\mathrm{e}$ & 1 & o & - & - & - & 12 & 5.62 & 0.8 & 24.0 & 113 & $\mathrm{~N}$ & No & NA \\
\hline & Monopis spilotella & $\mathrm{a}$ & $\mathrm{e}$ & 1 & o & - & - & - & 14 & 7.06 & 1.0 & 33.7 & 115 & $\mathrm{~N}$ & 3 & 0.191 \\
\hline Psychidae & Taleporia borealis & $\mathrm{a}$ & $\mathrm{e}$ & 1 & o & - & - & - & 18 & 3.43 & 0.0 & 20.7 & 143 & NS & 2 & 0.213 \\
\hline Gracillariidae & Parornix betulae & $\mathrm{a}$ & 1 & $\mathrm{p}$ & $\mathrm{p}$ & $\mathrm{m}$ & $\mathrm{w}$ & 1 & 7 & 0.78 & 0.0 & 3.7 & 113 & $\mathrm{~N}$ & 2 & 0.329 \\
\hline \multirow[t]{2}{*}{ Yponomeutidae } & $\begin{array}{l}\text { Paraswammerdamia } \\
\text { conspersella }\end{array}$ & $\mathrm{b}$ & $\mathrm{e}$ & 1 & $\mathrm{p}$ & $\mathrm{c}$ & $\mathrm{w}$ & 1 & 12 & 77.99 & 7.0 & 280.3 & 54 & NS & 3 & 0.492 \\
\hline & Argyresthia pygmaella & $\mathrm{a}$ & e & 1 & $\mathrm{p}$ & $\mathrm{b}$ & $\mathrm{w}$ & 1 & 12 & 8.02 & 0.0 & 23.0 & 99 & $\mathrm{P}$ & No & NA \\
\hline \multirow[t]{3}{*}{ Oecophoridae } & Denisia similella & a & $\mathrm{e}$ & 1 & o & - & - & - & 13 & 2.97 & 0.0 & 7.7 & 72 & $\mathrm{~N}$ & 3 & 0.517 \\
\hline & Denisia stipella & a & $\mathrm{e}$ & 1 & o & - & - & - & 17 & 31.78 & 9.0 & 76.0 & 60 & NS & No & NA \\
\hline & Pleurota bicostella & $\mathrm{a}$ & $\mathrm{e}$ & 1 & $\mathrm{p}$ & $\mathrm{c}$ & $\mathrm{w}$ & 2 & 21 & 11.27 & 2.0 & 31.3 & 83 & NS & No & NA \\
\hline Momphidae & Mompha idaei & a & $\mathrm{e}$ & 1 & $\mathrm{p}$ & $\mathrm{b}$ & $\mathrm{h}$ & 1 & 20 & 0.88 & 0.0 & 3.2 & 106 & NS & No & NA \\
\hline \multirow[t]{4}{*}{ Coleophoridae } & Coleophora idaeella & a & $\mathrm{e}$ & 1 & $\mathrm{p}$ & $\mathrm{m}$ & $\mathrm{b}$ & 2 & 13 & 0.86 & 0.0 & 4.0 & 108 & $\mathrm{P}$ & 2 & 0.234 \\
\hline & Coleophora vacciniella & $\mathrm{a}$ & e & 1 & $\mathrm{p}$ & $\mathrm{m}$ & w & 1 & 10 & 1.17 & 0.0 & 4.0 & 91 & NS & No & NA \\
\hline & Coleophora glitzella & $\mathrm{a}$ & e & 1 & $\mathrm{p}$ & $\mathrm{m}$ & w & 1 & 12 & 14.57 & 0.3 & 68.0 & 107 & $\mathrm{P}$ & 3 & 0.445 \\
\hline & Coleophora murinella & $\mathrm{a}$ & e & 1 & $\mathrm{p}$ & $\mathrm{m}$ & $\mathrm{w}$ & 1 & 13 & 6.47 & 0.2 & 41.0 & 128 & $\mathrm{P}$ & 2 & 0.320 \\
\hline \multirow[t]{4}{*}{ Gelechiidae } & Bryotropha galbanella & $\mathrm{a}$ & e & 1 & o & - & - & - & 15 & 8.13 & 1.5 & 24.7 & 82 & NS & No & NA \\
\hline & Chionodes lugubrella & $\mathrm{a}$ & e & 1 & $\mathrm{p}$ & $\mathrm{r}$ & $\mathrm{h}$ & 2 & 16 & 11.63 & 3.0 & 34.7 & 69 & $\mathrm{~N}$ & 2 & 0.115 \\
\hline & Chionodes continuella & a & $\mathrm{e}$ & 1 & o & - & - & - & 16 & 5.96 & 0.8 & 29.7 & 105 & $\mathrm{~N}$ & No & NA \\
\hline & Neofaculta infernella & $\mathrm{a}$ & e & 1 & $\mathrm{p}$ & $\mathrm{r}$ & $\mathrm{w}$ & 3 & 18 & 1.42 & 0.0 & 11.0 & 151 & NS & No & NA \\
\hline \multirow[t]{11}{*}{ Tortricidae } & Eana osseana & $\mathrm{a}$ & $\mathrm{e}$ & 1 & $\mathrm{p}$ & $\mathrm{b}$ & $\mathrm{h}$ & 3 & 22 & 10.20 & 0.5 & 69.0 & 147 & NS & 3 & 0.475 \\
\hline & Lozotaenia forsterana & a & $\mathrm{e}$ & $?$ & $\mathrm{p}$ & $\mathrm{r}$ & $\mathrm{b}$ & 3 & 23 & 1.24 & 0.0 & 6.0 & 125 & NS & 1 & 0.168 \\
\hline & Eulia ministrana & $\mathrm{a}$ & $\mathrm{e}$ & 1 & $\mathrm{p}$ & $\mathrm{r}$ & $\mathrm{w}$ & 3 & 23 & 1.69 & 0.0 & 7.5 & 118 & NS & 3 & 0.181 \\
\hline & Sparganotis rubicundana & a & e & 1 & $\mathrm{p}$ & $\mathrm{r}$ & $\mathrm{w}$ & 3 & 17 & 9.99 & 1.5 & 31.0 & 65 & NS & No & NA \\
\hline & Apotomis boreana & $\mathrm{b}$ & $\mathrm{e}$ & 1 & $\mathrm{p}$ & $\mathrm{r}$ & $\mathrm{w}$ & 1 & 17 & 1.85 & 0.0 & 14.0 & 108 & NS & 2 & 0.431 \\
\hline & Phiaris heinrichana & $\mathrm{b}$ & e & 1 & $\mathrm{p}$ & $\mathrm{r}$ & $\mathrm{w}$ & 1 & 18 & 30.51 & 1.7 & 128.0 & 62 & NS & 2 & 0.197 \\
\hline & Phiaris obsoletana & $\mathrm{a}$ & e & 1 & $\mathrm{p}$ & $\mathrm{r}$ & $\mathrm{w}$ & 1 & 17 & 21.81 & 1.7 & 58.7 & 70 & NS & No & NA \\
\hline & Phiaris schulzianus & a & $\mathrm{e}$ & 1 & $\mathrm{p}$ & $\mathrm{r}$ & $\mathrm{w}$ & 3 & 22 & 19.85 & 0.5 & 275.0 & 267 & NS & 2 & NA \\
\hline & Ancylis myrtillana & $\mathrm{a}$ & $\mathrm{e}$ & 1 & $\mathrm{p}$ & $\mathrm{r}$ & $\mathrm{w}$ & 3 & 14 & 40.18 & 1.2 & 179.0 & 103 & NS & 2 & 0.280 \\
\hline & Epinotia solandriana & a & $\mathrm{e}$ & $?$ & $\mathrm{p}$ & $\mathrm{r}$ & $\mathrm{w}$ & 2 & 21 & 1.73 & 0.0 & 10.7 & 144 & $\mathrm{P}$ & No & NA \\
\hline & Gypsonoma nitidulana & $\mathrm{b}$ & 1 & 1 & $\mathrm{p}$ & $\mathrm{r}$ & $\mathrm{w}$ & 1 & 16 & 1.80 & 0.0 & 16.5 & 132 & NS & No & NA \\
\hline Pyralidae & Eudonia murana & a & $\mathrm{e}$ & 1 & o & - & - & - & 16 & 3.34 & 0.0 & 28.7 & 166 & NS & No & NA \\
\hline Lasiocampidae & Poecilocampa populi & $\mathrm{a}$ & e & $\mathrm{e}$ & $\mathrm{p}$ & $\mathrm{c}$ & $\mathrm{b}$ & 2 & 35 & 2.91 & 0.0 & 16.7 & 150 & NS & No & NA \\
\hline \multirow[t]{5}{*}{ Geometridae } & Scopula ternata & $\mathrm{a}$ & $\mathrm{e}$ & 1 & $\mathrm{p}$ & $\mathrm{c}$ & $\mathrm{w}$ & 2 & 23 & 10.79 & 0.5 & 25.7 & 75 & NS & No & NA \\
\hline & Xanthorhoe decoloraria & a & $\mathrm{e}$ & 1 & $\mathrm{p}$ & $\mathrm{c}$ & $\mathrm{h}$ & 2 & 25 & 2.12 & 0.0 & 6.0 & 83 & NS & 2 & 0.263 \\
\hline & Entephria caesiata & $\mathrm{a}$ & $\mathrm{e}$ & 1 & $\mathrm{p}$ & $\mathrm{c}$ & w & 3 & 28 & 103.87 & 5.2 & 490.0 & 126 & NS & 2 & 0.552 \\
\hline & Eulithis populata & $\mathrm{a}$ & $\mathrm{e}$ & $\mathrm{e}$ & $\mathrm{p}$ & $\mathrm{c}$ & $\mathrm{b}$ & 2 & 29 & 26.66 & 0.8 & 129.0 & 101 & $\mathrm{P}$ & 2 & 0.359 \\
\hline & Epirrita autumnata & $\mathrm{a}$ & $\mathrm{e}$ & $\mathrm{e}$ & $\mathrm{p}$ & $\mathrm{c}$ & $\mathrm{b}$ & 2 & 43 & 1716.45 & 22.0 & 29450.0 & 334 & NS & 1 & 0.261 \\
\hline \multirow[t]{2}{*}{ Noctuidae } & Xestia tecta & $\mathrm{b}$ & $\mathrm{e}$ & 1 & $\mathrm{p}$ & $\mathrm{c}$ & w & 2 & 36 & 1.11 & 0.0 & 4.8 & 93 & NS & No & NA \\
\hline & Xestia alpicola & $\mathrm{b}$ & e & 1 & $\mathrm{p}$ & $\mathrm{c}$ & $\mathrm{w}$ & 3 & 35 & 5.85 & 0.0 & 76.0 & 173 & NS & 2 & 0.564 \\
\hline
\end{tabular}

Life-cycle characters: $F P$ flight periodicity ( $a$ annual, $b$ biennial), $P T$ timing of pupation ( $e$ early in the season, $l$ late in the season), $H I$ overwintering stage ( $e$ egg, $l$ larva, $p$ pupa), $L F$ larval food ( $p$ alive vascular plants, $o$ other), $F G$ larval feeding guild ( $c$ chewer, $m$ leaf miner, $r$ leaf roller, $b$ shoot/root borer), $H P$ host-plant life form ( $h$ herbaceous, $w$ woody plants, $b$ both forms), $S P$ larval specialisation (1, feeding in one plant genus; 2 , in 2 genera; 3 , in 3 or more genera). Question marks indicate insufficient knowledge on life-history characteristic. Catches of species with biennial flight periodicity are summarised for two consecutive years; magnitudes of fluctuation were measured by the coefficient of variation (CV). Any linear trend was detected by time-series analyses: $P$ positive (i.e., increase in catches during the sampling period), $N$ negative, $N S$ non-significant. The time lag in years refers to the maximum time lag represented in time-series models (e.g., a model with time lag $=3$ also includes terms for time lags of 1 and 2 years) 
estimates for autoregressive models (Price and Hunter 2005; Redfern and Hunter 2005). With the standard assumption of log-linear relationships in the data (Stenseth et al. 1996), we used the model structure and methods described by Royama (1992) and Forchhammer et al. (1998) to develop time-delayed models for each moth population. Models were of the form:

$x_{t}=\left(1+\alpha_{1}\right) x_{t-1}+\alpha_{2} x_{t-2}+\cdots+\alpha_{D} x_{t-D}$,

where $x=\log _{\mathrm{e}}(1+$ moth abundance $)$ at a given time $t$, and the $\alpha$ are the strength of density-dependent effects on various time lags $(D)$. We used the corrected Akaike's information criterion $\left(\mathrm{AIC}_{\mathrm{c}}\right)$ to select among competing models (Forchhammer et al. 1998). The $\mathrm{AIC}_{\mathrm{c}}$ values provide a measure of parsimony by which to choose models with the maximum information gain for the minimum number of model variables. In all cases, the maximum time lag investigated in our models was 3 years, the maximum lag for which ecological meaning can be easily inferred (Royama 1992). AIC $\mathrm{A}_{\mathrm{c}}$ values compare among models of increasing complexity. Specifically, a model with time lags of both 1 and 2 years is compared with a model with only a 1-year time lag. Likewise, a model with time lags of 1, 2 and 3 years is compared with models with fewer lags. The most parsimonious models are those with the lowest $\mathrm{AIC}_{\mathrm{c}}$ values (Forchhammer et al. 1998).

Data were missing from 1980 to 1982 for nine moth species. For these species, models were developed using population counts from 1983 to 1997 only. Counts for all other univoltine species were developed using data from 1972 to 1997 . Population counts for 12 species that demonstrated significant linear trends were detrended using a linear model before model fitting (Hunter et al. 1997).

Seven moth species (Table 1) were hemivoltine, exhibiting 2-year life cycles. Hemivoltinism was confirmed in these species, either because they were caught almost exclusively in alternate years (i.e., a single hemivoltine population. as in Xestia tecta, X. alpicola and Gypsonoma nitidulana) or because they exhibited highly significant positive correlations between population counts that were separated by 2 years (species with both odd-year and evenyear hemivoltine populations, as in Paraswammerdamia conspersella and Phiaris heinrichana). Time-series models for the hemivoltine moth species were therefore developed using data from alternate years (e.g., Redfern and Hunter 2005). Models developed for even- and odd-year hemivoltine populations did not differ qualitatively and so evenyear models are reported here (i.e., for $P$. conspersella and $P h$. heinrichana). Population counts for the final hemivoltine species, Ectoedemia weaveri, were missing from 1980 to 1982 - we concluded that the available time series was too short for valid analysis.
Data exploration

The results of autocorrelation analyses were used as classificatory variables in both analyses of variance (ANOVAs) (type III sum of squares; SAS GLM procedure) for continuous data (mean annual catches, $\mathrm{CV}$ in annual catches, and moth wing span) and frequency analyses (SAS FREQ procedure) for other data (moth phylogenetic position and life-history traits). First, we contrasted species with and without negative feedbacks; second, we compared species showing different time lags in negative feedback; and finally, we compared four classes altogether (no apparent negative feedback, and time lags of 1,2 and 3 years). We also searched for relationships among continuous variables by calculation of correlation coefficients (SAS CORR procedure; SAS Institute 2009).

\section{Results}

Differences between rare and abundant species

Average annual catches of 42 species classified as abundant ranged from 0.78 to 1716 specimens per trap (Table 1). Log-transformed values of annual catches of these species were normally distributed $(P>0.05)$. Abundant species accounted for $97 \%$ of collected individuals, among which the autumnal moth, Epirrita autumnata (Bkh.), was the most frequent species $(77 \%$ of total catch).

Most of the 190 species classified as 'rare' were infrequent during the entire study period: maximum annual catches in 132 species never exceeded 1 specimen/trap. Distributions of annual/biennial mean catches of these species were generally skewed due to overrepresentation of zero values, and log transformation did not remove this skewness.

Species hibernating in the larval stage (and whose larvae pupate during the first half of the season) and species whose larvae fed on substrates other than chlorophyllcontaining organs of vascular plants were 1.5-2.5 times more frequent among abundant species than among rare species (Table 2). Herbivorous species with different larval feeding strategies (feeding habit, feeding guild, specialisation, host life form) were proportionally distributed among rare and abundant species (Table 2). Rare and abundant species had similar mean wing lengths [mean \pm standard error (SE): $18.2 \pm 0.7$ and $18.6 \pm 1.2 \mathrm{~mm}$, respectively; $\left.F_{1,230}=0.57, P=0.45\right]$ and were proportionally represented among the major phylogenetic lineages of Lepidoptera $\left(\chi_{5}^{2}=6.06, P=0.30\right)$ (Fig. 1$)$. 
Table 2 Comparison of life-history characteristics between rare (RA) and abundant (AB) moth species collected at the Kevo Subarctic Research Institute, northern Finland, between 1972 and 1997

\begin{tabular}{|c|c|c|c|c|c|c|}
\hline \multirow[t]{2}{*}{ Species considered } & \multicolumn{2}{|l|}{ Life history characters } & \multicolumn{2}{|c|}{ Species numbers } & \multicolumn{2}{|c|}{ Statistics } \\
\hline & Type & Category & RA & $\mathrm{AB}$ & $\chi^{2}$ & $P$ \\
\hline \multirow[t]{8}{*}{ All } & \multirow[t]{4}{*}{ Overwintering stage } & Egg & 18 & 3 & \multirow[t]{4}{*}{11.83} & \multirow[t]{4}{*}{0.008} \\
\hline & & Larva & 71 & 33 & & \\
\hline & & Pupa & 27 & 2 & & \\
\hline & & Imago & 8 & 0 & & \\
\hline & \multirow[t]{2}{*}{ Pupation period } & Early & 119 & 37 & \multirow[t]{2}{*}{9.08} & \multirow[t]{2}{*}{0.003} \\
\hline & & Late & 53 & 3 & & \\
\hline & \multirow[t]{2}{*}{ Larval food } & Green plants & 176 & 31 & \multirow[t]{2}{*}{5.16} & \multirow[t]{2}{*}{0.02} \\
\hline & & Other & 16 & 8 & & \\
\hline \multirow[t]{12}{*}{ Herbivorous } & \multirow[t]{2}{*}{ Larval feeding habit } & Exophagous & 108 & 22 & \multirow[t]{2}{*}{0.52} & \multirow[t]{2}{*}{0.47} \\
\hline & & Endophagous & 66 & 10 & & \\
\hline & \multirow[t]{4}{*}{ Larval feeding guild } & Chewers & 60 & 10 & \multirow[t]{4}{*}{3.94} & \multirow[t]{4}{*}{0.27} \\
\hline & & Rollers & 38 & 12 & & \\
\hline & & Borers & 25 & 2 & & \\
\hline & & Miners & 41 & 8 & & \\
\hline & \multirow[t]{3}{*}{ Host-plant life form } & Herbaceous & 40 & 6 & \multirow[t]{3}{*}{2.90} & \multirow[t]{3}{*}{0.24} \\
\hline & & Woody & 105 & 19 & & \\
\hline & & Both & 24 & 7 & & \\
\hline & \multirow[t]{3}{*}{ Feeding specialisation } & Monophagous & 74 & 11 & \multirow[t]{3}{*}{2.27} & \multirow[t]{3}{*}{0.32} \\
\hline & & Oligophagous & 46 & 13 & & \\
\hline & & Polyphagous & 47 & 8 & & \\
\hline
\end{tabular}

Directional changes in abundance

In preliminary time-series analyses (SAS 9.2 time-series forecasting procedure), we found significant linear trends in population counts (on a log scale) in 12 of the moth species (Table 1; Fig. 2a-e). However, only 3 of 42 abundant species demonstrated directional changes in annual catches that were significant at the table-wide probability level $P=0.05$. The abundance of Chionodes continuellus (Z.) declined (Fig. 2c) whereas catches of Argyresthia pygmaeella (Den. et Schiff.) (Fig. 2b) and Eulithis populata (L.) (Fig. 2e) increased over the observation period (1972-1997).

Coefficient of variation in annual catches of abundant species

The CV in annual catches of species hibernating as eggs was 1.8 times larger than that of species hibernating as larvae or pupae $\left(F_{1,36}=8.52, P=0.006\right)$. Among species feeding on the green parts of vascular plants, the CV in annual catches generally increased with the degree of polyphagy $\left(F_{1,40}=4.75, P=0.04\right)$. Species feeding on both woody and herbaceous plants exhibited much larger $\mathrm{CV}$ than species feeding on either woody or herbaceous plants alone (mean \pm SE: $164 \pm 43 \%$ vs. $111 \pm 7 \%$ ), and the $\mathrm{CV}$ in annual catches increased from species feeding in one plant genus $(97 \pm 7 \%)$ to species feeding in two $(124 \pm 25 \%)$ and more plant genera $(142 \pm 19 \%)$.

None of the other tests in which we correlated annual variability in population counts with life-history traits (listed in Table 2), taxonomic position of species (classified as in Fig. 1), moth family or moth size yielded significant results $(P$ values in separate tests ranged from 0.22 to 0.98 ) with one exception: larger species of Lepidoptera exhibited higher $\mathrm{CV}$ in annual catches $(r=0.47, n=42$, $P=0.0015)$.

Time lags in negative feedback in annual catches of abundant species

Statistically significant time lags in negative feedback were found in 22 of 41 abundant species (Table 1). The planned contrast between abundant species showing and not showing statistically significant time lags revealed no differences in any of the continuous variables examined, such as mean annual catches, $\mathrm{CV}$ in annual catches, and wing span. Likewise, frequency analysis performed with all of the categorical life-history traits listed in Table 2 yielded no significant results. Similarly, we found no variation in 

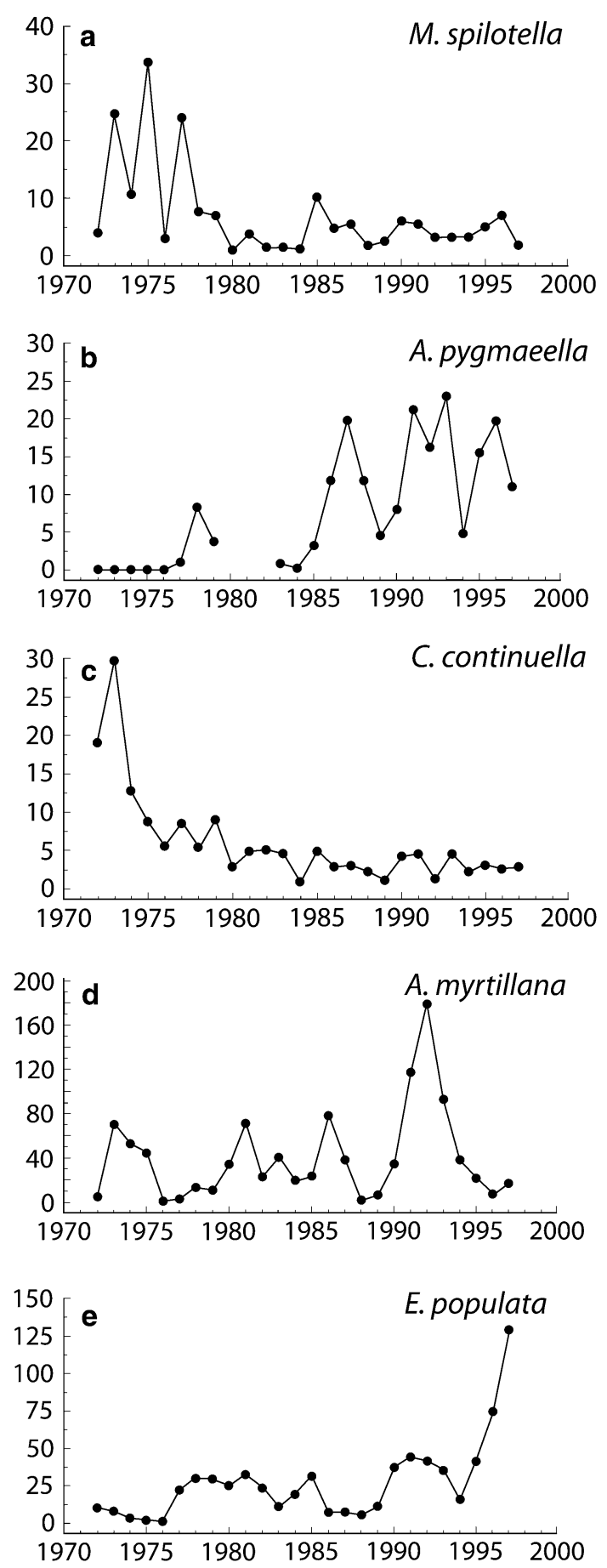

Fig. 2 Density fluctuations (expressed as the mean number per trap per year) in moth species with different life-history traits collected at the Kevo Subarctic Research Institute, northern Finland, between 1972 and 1997. Time lag refers to the maximum order of time lag represented in time-series models. a Monopis spilotella (Spearman rank correlation between annual catch and study year: $r_{\mathrm{S}}=-0.31, P=0.12$; time lag 3 years). b Argyresthia pygmaella $\left(r_{\mathrm{S}}=0.81, P=0.0001\right.$; no time lag). c Chionodes continuellus ( $r_{\mathrm{S}}=-0.77, P=0.0001$; no time lag). d Ancylis myrtillana $\left(r_{\mathrm{S}}=0.14, P=0.50\right.$; time lag 2 years). e Eulithis populata $\left(r_{\mathrm{S}}=0.63, P=0.0005\right.$; time lag 2 years $)$ any character analysed among species demonstrating time lags of 1, 2 or 3 years. However, when all four classes of species (showing no time lag, and showing time lags of 1,2 and 3 years) were analysed together, variation in the CV in annual catches approached the significance level $\left(F_{3,37}=2.70, P=0.06\right)$. The post hoc Duncan test demonstrated that this variation is mostly due to a significantly higher $\mathrm{CV}$ in species exhibiting 1-year time lags (mean \pm SE: $194 \pm 70 \%$ ) compared with species exhibiting no time lags $(118 \pm 11 \%)$ or longer time lags ( 2 years: $110 \pm 9 \%$; 3 years: $102 \pm 14 \%$ ).

We detected significant variation among moth families in $\alpha_{1}$ coefficients $\left(F_{10,10}=2.89, P=0.05\right)$, suggesting at least a weak phylogenetic signal in density dependence at the family level. In spite of that, species within the same genus generally showed different patterns of density dependence. This is especially intriguing for species pairs such as Incurvaria, Monopis, and Denisia, which are very closely related and have similar life-history traits (Table 2).

\section{Discussion}

Rarity and abundance

Our data, like multiyear observations on herbivorous insects on bracken in England (Lawton and Gaston 1989), demonstrate that rare species have generally remained rare over the 26-year study period, and that rare species differ in life-history traits from those that are more abundant (as suggested by Kunin and Gaston 1993). Intriguingly, species whose larvae feed on substrates other than living vascular plants (generally detritus, sometimes mosses) are over-represented among abundant species $(20.5 \%$ compared with $8.3 \%$ among rare species). This finding fits the general concept of environmental predictability (Southwood 1977; Ariño and Pimm 1995), since variations in both amount and quality of food are presumably lower for larvae feeding on detritus or mosses than on green parts of vascular plants.

Hibernation at the larval stage (associated with pupation during the first half of the plant-growing season, Table 2) allows exploitation of early summer (flushing) foliage, which is generally better quality food for herbivores (Slansky and Rodriguez 1987; Martel and Kause 2002; Murakami et al. 2005). This can be seen as one of the reasons behind higher overall abundance of this species group in our catches. However, we cannot completely exclude the hypothesis that this pattern emerged due to sampling bias: the species that pupate during the first half 
of the growing season fly from mid-summer to early autumn when the efficiency of light traps is presumably higher than during the light nights of the first half of the summer.

\section{Magnitude of fluctuations in abundance}

Several ecological and life-history factors may be linked with the magnitude of temporal variability in population size (reviewed by Gaston and McArdle 1994). Density fluctuations have been associated with monophagy (MacArthur 1955; Redfearn and Pimm 1988), high fecundity (Spitzer et al. 1984), feeding in early spring, gregarious feeding habit, eggs placed in clusters, larval defences other than crypsis (Hunter 1991, 1995a), wing reduction in females (Hunter 1995b), feeding on annual rather than perennial plants (van Emden and Way 1972), female selectivity in respect of oviposition substrate (Price 1990, 1994, 2003; Price et al. 1990; Tammaru et al. 1995) or oviposition behaviour (Eber et al. 2001), presence/absence of imaginal feeding (Tammaru and Haukioja 1996) and the strength of bottom-up regulation (Eber et al. 2001). Furthermore, moth size may contribute to population variability either directly (Gaston 1988) or via some of the characteristics listed above (Wasserman and Mitter 1978; Niemelä et al. 1981; Gaston 1988; Inkinen 1994; Lindström et al. 1994). The problem, of course, is that these patterns were extracted from different data sets and by using different approaches, and only some of these patterns could be verified by using our data set. Last but not least, outbreaks of some species (such as autumnal moth Epirrita autumnata) occur only in some parts of the distributional range (Tenow 1972; Ruohomäki et al. 2000), emphasising the importance of environmental factors in shaping outbreaking population dynamics.

Hibernation at the egg stage and pupation during the second half of the plant-growing season in our analyses were strongly associated with high $\mathrm{CV}$ in annual catches. This result is consistent with earlier observations that, along with the autumnal moth Epirrita autumnata, a notorious outbreaking species with the highest $\mathrm{CV}$ in annual catches in our data set, many outbreaking species such as green tortrix, Tortrix viridana (L.), winter moth, Operophtera brumata (L.), and gypsy moth, Lymantria dispar (L.), overwinter as eggs (Price 1997). More generally, outbreaking species of Canadian macrolepidopterans have also been reported to be synchronised with flushing foliage (Hunter 1991, 1995a).

Early season foliage appears to be a less predictable resource than late season foliage, and this may explain why pupation early in the season, associated with feeding on flushing foliage, is related to a higher $\mathrm{CV}$ in annual catches compared with species feeding on late season (mature) foliage. However, the same theory predicts that polyphagous species should be less variable than host specialists, the pattern confirmed by Redfearn and Pimm (1988) but not found in our data set. Instead, our results (higher variability of polyphagous species, especially of those feeding on both woody and herbaceous plants) are in agreement with the concept by Watt (1964) and empirical results by Rejmanek and Spitzer (1982). This controversy may hint that the detected patterns are driven by life-history traits other than the level of host-plant specialization, but these traits still remain to be discovered.

\section{Periodicity in fluctuations of species' abundance}

Cyclic population dynamics have been reported (Myers 1988) and statistically analysed (Turchin 1990) in several outbreaking temperate forest moths, whereas periodicity in fluctuations of non-outbreaking moth species has not, to our knowledge, been reported previously. Systems tend to oscillate if there are delayed negative feedbacks (Berryman 1987), and second-order (=delayed) processes were found in over $50 \%$ of cases analysed and interpreted by Turchin (1990). Similarly, we found that about half of the abundant species investigated here exhibited delayed density dependence (Table 1).

The prevalence and detection of density dependence have been the subject of considerable debate for many years (Andrewarth and Birch 1954; Lack 1954; Pollard et al. 1987; Stiling 1988; Dennis and Taper 1994; Williams and Liebhold 1995; Hunter and Price 1998). A lack of strong negative feedback may reflect the dominance of local stochastic factors (e.g., weather) or density-independent movement (e.g., dispersal) in driving population dynamics (Hunter 2001). Additionally, light-trap data may be particularly susceptible to environmental influence (temperature, moonlight etc.), thus decreasing our ability to detect a signal of density dependence. Whatever the cause, the abundances of nearly half of the moth species that we investigated appear to fluctuate without the action of strong local negative feedback.

Models of population cycles generally invoke either higher (natural enemies) or lower (host quality) trophic levels, or relate the quality of individuals themselves to patterns of abundance (Voipio 1950; Chitty 1960; Ginzburg and Taneyhill 1994; Rossiter 1994; Zvereva et al. 2002). Although cycles generated by these mechanisms are often indistinguishable from each other (Ginzburg and Taneyhill 1994), our data indirectly indicate that host-plant quality or quantity may regulate populations of some of the herbivorous moths. For example, the higher CV in annual catches of larger moths may be explained by the higher levels of damage that larger species may cause to their hosts. If severe defoliation induces rapid increases in 
defence, then periodic dynamics can result (Hunter 2001). Similarly, moth species with the shortest time lags in negative feedback ( 1 year) had the largest magnitude of fluctuations in our study; first-order feedback processes are often associated with competition for limited resources or rapid defence induction (Hunter 1998). However, defence induction is definitely not the only mechanism causing density oscillations in the Kevo moth community, because delayed density dependence was also found in three species whose larvae feed on plant detritus or on mosses (Table 1).

Fluctuations in species' abundance and phylogeny of Lepidoptera

Our findings support the conclusion reached by Hunter (1991, 1995a) on the absence of strict phylogenetic constraints underlying moth population dynamics. In particular, different population dynamics found in closely related moth species with similar life-history traits undermines the phylogenetic constraints hypothesis. This result is also in line with studies of plant extinction, which reveal that extinction risk cannot be reliably predicted from species' traits alone (Freville et al. 2007). However, as long as population dynamics is properly documented in only a few species, with no representatives from the most archaic lineages of Lepidoptera (except for periodic fluctuations reported for Eriocrania spp.: Bylund and Tenow 1994; Zvereva and Kozlov 2006), this conclusion should be regarded as tentative.

\section{Conclusions}

Our analyses reveal that only a few consistent patterns in the population dynamics of herbivorous moths can be deduced from life-history characteristics of the species, and the diversity of population behaviour in one moth assemblage challenges any conventional wisdom suggesting predictable patterns. The population variability of the moths forms a continuum from latent to eruptive species, rather than a simple dichotomy of 'outbreaking' and 'other' species. The continuum approach should be preferred in studies emphasising an evolutionary perspective and will likely provide better opportunities to understand the mechanisms driving such an array of dynamics. Our results raise several questions about perceptions and paradigms in insect population dynamics and stress the need for research on detritivorous insect population dynamics, as well as the need for more assemblagewide studies using common trapping methods to provide comparative data on related and unrelated species with different life-history traits. And finally, there is an urgent need for reliable multiyear data on fluctuations in abundance of rare species, which are under-represented in all data sets published so far.

Acknowledgments Many individuals contributed to the creation of the data set used in this publication $\left({ }^{+}\right.$denotes deceased). We warmly thank the station heads $\left({ }^{+}\right.$P. Kallio, E. Haukioja and S. Neuvonen) and staff of the Kevo Subarctic Research Institute for study facilities and generous help in the work. L. Iso-Iivari was primarily responsible for trap maintenance and sampling of the material. Many persons participated in sorting the material; E. Zvereva who sorted samples from 1985 to 1994 , is specially acknowledged. Responsibility for determination of moths sampled during 1971-1982 was taken by ${ }^{+} \mathrm{E}$. T. Linnaluoto; later samples were mostly determined by M. Kozlov. Our thanks to ${ }^{+}$J. Jalava, L. Kaila, ${ }^{+}$J. Kyrki, K. Mikkola, K. Ruohomäki, L. Sippola, T. Tammaru and many other specialists who helped us with identification and shared with us biological data not generally available through publications. E. Zvereva, ${ }^{+}$E. Ranta, T. Tammaru, M. Ayres and two anonymous reviewers provided valuable comments on an earlier draft of the manuscript. Financial support was provided by the Academy of Finland (projects no. 1071299, 2228, 122133 and Centre of Excellence for Forest Ecology and Management project 64308), and the EU BALANCE project carried out under contract EVK2-2002-00169.

\section{References}

Andrewarth HG, Birch LC (1954) The distribution and abundance of animals. University of Chicago Press, Chicago

Ariño A, Pimm LS (1995) On the nature of population extremes. Evol Ecol 9:429-443

Berryman AA (1987) The theory and classification of outbreaks. In: Barbosa P, Schultz JC (eds) Insect outbreaks. Academic, San Diego, pp 3-30

Berryman AA (1994) Population dynamics: forecasting and diagnosis from time series. In: Leather SR, Watt AD, Mills NJ, Walters KFA (eds) Individuals populations and patterns in ecology. Intercept, Andover, pp 119-128

Bylund H, Tenow O (1994) Long-term dynamics of leaf miners Erocrania spp., on mountain birch: alternate year fluctuations and interaction with Epirrita autumnata. Ecol Entomol 19:310 318

Chitty D (1960) Population processes in the vole and their relevance to general theory. Can J Zool 38:99-113

Dennis B, Taper ML (1994) Density dependence in time series observations of natural populations: estimation and testing. Ecol Monogr 64:205-224

Eber S, Smith HP, Didham RK, Cornell HV (2001) Holly leaf-miners on two continents: what makes an outbreak species? Ecol Entomol 26:124-132

Faeth SH (1987) Community structure and folivorous insect outbreaks: the roles of vertical and horizontal interactions. In: Barbosa P, Schultz JC (eds) Insect outbreaks. Academic, San Diego, pp 135-171

Forchhammer MC, Stenseth NC, Post E, Langvatn R (1998) Population dynamics of Norwegian red deer: density-dependence and climatic variation. Proc R Soc B 265:341-350

Freville H, McConway K, Dodd M, Silvertown J (2007) Prediction of extinction in plants: interaction of extrinsic threats and life history traits. Ecology 88:2662-2672

Gaston KJ (1988) Patterns in the local and regional dynamics of moth populations. Oikos 53:49-57

Gaston KJ, McArdle BH (1994) The temporal variability of animal abundances: measures, methods and patterns. Philos Trans R Soc B Biol Sci 345:335-358 
Ginzburg LR, Taneyhill DE (1994) Population cycles of forest Lepidoptera: a maternal effect hypothesis. J Anim Ecol 63:7992

Haukioja E (2005) Plant defenses and population fluctuations of forest defoliators: mechanism-based scenarios. Ann Zool Fenn 42:313325

Haukioja E, Niemelä P, Iso-Iivari L, Ojala H, Aro E-M (1978) Birch leaves as a resource for herbivores. I. Variation in the suitability of leaves. Rep Kevo Subarctic Res Stn 14:5-12

Hunter AF (1991) Traits that distinguish outbreaking and nonoutbreaking Macrolepidoptera feeding on northern hardwood trees. Oikos 60:275-282

Hunter AF (1995a) Ecology, life history, and phylogeny of outbreak and nonoutbreak species. In: Cappuccino N, Price PW (eds) Population dynamics: new approaches and synthesis. Academic, London, pp 41-64

Hunter AF (1995b) The ecology and evolution of reduced wings in forest macrolepidoptera. Evol Ecol 9:275-287

Hunter MD (1998) Interactions between Operophtera brumata (Lepidoptera: Geometridae) and Tortix viridana (Lepidoptera: Tortricidae) on oak: new evidence from time-series analysis. Ecol Entomol 23:168-173

Hunter MD (2001) Multiple approaches to estimating the relative importance of top-down and bottom-up forces on insect populations: experiments, life tables, and time-series analysis. Basic Appl Ecol 2:295-309

Hunter MD, Price PW (1998) Cycles in insect populations: delayed density dependence or exogenous driving variables? Ecol Entomol 23:216-222

Hunter MD, Varley GC, Gradwell GR (1997) Estimating the relative roles of top-down and bottom-up forces on insect herbivore populations: a classic study re-visited. Proc Natl Acad Sci USA 94:9176-9181

Inkinen P (1994) Distribution and abundance in British noctuid moths revisited. Ann Zool Fenn 31:235-243

Jalas I (1960) Eine leichtgebaute, leichttransportable Lichtreuse zum Fangen von Schmetterlingen. Ann Entomol Fenn 26:44-50

Kallio P (1975) Kevo, Finland. Ecol Bull 20:193-223

Kallio P, Laine U, Mäkinen Y (1969) Vascular flora of Inari Lapland. 1. Introduction and Lycopodiaceae-Polypodiaceae. Rep Kevo Subarctic Res Stn 5:1-108

Karvonen J, Laasonen EM, Aalto A, Kerppola S, Karvonen EV (1979) Lepidoptera species new to Finland, caught with continuous light trapping. Not Entomol 59:153-158

Kremen C (1992) Assessing the indicator properties of species assemblages for natural areas monitoring. Ecol Appl 2:203-217

Kristensen NP, Skalski AW (1998) Palaeontology and phylogeny. Lepidoptera: moths and butterflies 1. In: Kristensen NP (ed) Handbuch der Zoologie/Handbook of zoology, vol IV/35. NP Walter de Gruyter, Berlin, pp 7-25

Kullberg J, Albrecht A, Kaila L, Varis V (2002) Checklist of Finnish Lepidoptera-Suomen perhosten luettelo. Sahlbergia 6:45-190

Kunin WE, Gaston KJ (1993) The biology of rarity: patterns, causes, and consequences. Trends Ecol Evol 8:298-301

Lack D (1954) The natural regulation of animal numbers. Oxford University Press, New York

Lawton JH, Gaston KJ (1989) Temporal patterns in the herbivorous insects on bracken: a test of community predictability. J Anim Ecol 58:1021-1034

Lindström J, Kaila L, Niemelä P (1994) Polyphagy and adult body size in geometrid moths. Oecologia 98:130-132

Linnaluoto ET, Koponen S (1980) Lepidoptera of Utsjoki, northernmost Finland. Kevo Notes 5:1-68

Lokki J, Malmström K, Suomalainen E (1978) Migration of Vanessa cardui and Plutella xylostella (Lepidoptera) to Spitsbergen in the summer 1978. Not Entomol 58:121-123
MacArthur RH (1955) Fluctuations of animal populations and a measure of community stability. Ecology 36:533-536

Martel J, Kause A (2002) The phenological window of opportunity for early-season birch sawflies. Ecol Entomol 27:302-307

Mason RR (1987) Nonoutbreak species of forest Lepidoptera. In: Barbosa P, Schultz JC (eds) Insect outbreaks. Academic, San Diego, pp 31-57

Murakami M, Yoshida K, Hara H, Toda MJ (2005) Spatio-temporal variation in Lepidopteran larval assemblages associated with oak, Quercus crispula: the importance of leaf quality. Ecol Entomol 30:521-531

Myers JH (1988) Can a general hypothesis explain population cycles of forest Lepidoptera? Adv Ecol Res 18:179-242

New TR (1997) Are Lepidoptera an effective 'umbrella group' for biodiversity conservation? J Insect Conserv 1:5-12

Niemelä P, Hanhimäki S, Mannila R (1981) The relationship of adult size in noctuid moths (Lepidoptera, Noctuidae) to breadth of diet and growth form of host plants. Ann Entomol Fenn 47:17-20

Pollard E, Lakhani KH, Rothery P (1987) The detection of densitydependence from a series of annual censuses. Ecology 68:20462055

Price PW (1990) Insect herbivore population dynamics: is a new paradigm available? Symp Biol Hung 39:177-190

Price PW (1994) Phylogenetic constraints, adaptive syndromes, and emergent properties: from individuals to population dynamics. Res Popul Ecol 36:3-14

Price PW (1997) Insect ecology, 3rd edn. Wiley, NY

Price PW (2003) Macroevolutionary theory on macroecological patterns. Cambridge Univ Press, Cambridge

Price PW, Hunter MD (2005) Long-term population dynamics of a sawfly show strong bottom-up effects. J Anim Ecol 74:917-925

Price PW, Cobb N, Craig TP, Fernandes GW, Itami JK, Mopper S, Preszler RW (1990) Insect herbivore population dynamics on trees and shrubs: new approaches relevant to latent and eruptive species and life table development. In: Bernays EA (ed) Insectplant interactions, vol 2. CRC, Boca Raton, pp 1-38

Redfearn A, Pimm LS (1988) Population variability and polyphagy in herbivorous insect communities. Ecol Monogr 58:39-55

Redfern M, Hunter MD (2005) Time tells: long-term patterns in the population dynamics of the yew gall midge, Taxomyia taxi (Cecidomyiidae), over 35 years. Ecol Entomol 30:86-95

Rejmanek M, Spitzer K (1982) Bionomic strategies and long-term fluctuations in abundance of Noctuidae (Lepidoptera). Acta Entomol Bohemoslov 79:81-96

Rossiter MC (1994) Maternal effects hypothesis of herbivore outbreak. Bioscience 44:752-763

Royama T (1992) Analytical population dynamics. Chapman and Hall, London

Ruohomäki K, Tanhuanpää M, Ayres MP, Kaitaniemi P, Tammaru T, Haukioja E (2000) Causes of cyclicity of Epirrita autumnata (Lepidoptera, Geometridae): grandiose theory and tedious practice. Popul Ecol 42:211-223

SAS Institute (2009) SAS version 9.2 for Windows. SAS Institute, Cary

Seppälä M, Rastas J (1980) Vegetation map of northernmost Finland with special reference to subarctic forest limits and natural hazards. Fennia 158:41-61

Slansky F, Rodriguez JG (1987) Nutritional ecology of insects, mites, spiders and related invertebrates. Wiley, NY

Southwood TRE (1977) Habitat, the templet for ecological strategies? J Anim Ecol 46:337-365

Spitzer K, Rejmanek M, Soldan T (1984) The fecundity and longterm variability in abundance of noctuid moths (Lepidoptera, Noctuidae). Oecologia 62:91-93

Stenseth NC, Bjornstad ON, Falck W (1996) Is spacing behaviour coupled with predation causing the microtine density cycle? 
A synthesis of current process-oriented and pattern-oriented studies. Proc R Soc B 263:1423-1435

Stiling P (1988) Density-dependent processes and key factors in insect populations. J Anim Ecol 57:581-594

Tammaru T, Haukioja E (1996) Capital breeders and income breeders among Lepidoptera-consequences to population dynamics. Oikos 77:561-564

Tammaru T, Kaitaniemi P, Ruohomäki K (1995) Oviposition choices of Epirrita autumnata (Lepidoptera: Geometridae) in relation to its eruptive population dynamics. Oikos 74:296-304

Tenow O (1972) The outbreaks of Oporinia autumnata Bkh. and Operophthera spp. (Lep., Geometridae) in the Scandinavian mountain chain and northern Finland 1862-1968 (PhD thesis). Zoologiska Bidrag från Uppsala (Suppl 2):1-107

Turchin P (1990) Rarity of density dependence or regulation with lags? Nature 344:660-663

van Emden HF, Way MJ (1972) Host plants in the population dynamics of insects. In: van Emden HF (ed) Insect/plant relationships. Blackwell, Oxford, pp 181-199
Voipio P (1950) Evolution at the population level with special reference to the game animals and practical game management. Pap Game Res 5:1-176

Wasserman SS, Mitter C (1978) The relationship of body size to breadth of diet in some Lepidoptera. Ecol Entomol 3:155-160

Watt KEF (1964) Comments on fluctuations of animal populations and measures of community stability. Can Entomol 96:1434-1442

Williams DW, Liebhold AM (1995) Detection of delayed density dependence: effects of autocorrelation in an exogenous factor. Ecology 76:1005-1008

Wolda H, Marek J, Spitzer K, Is Novak (1994) Diversity and variability of Lepidoptera populations in urban Brno, Czech Republic. Eur J Entomol 91:213-226

Zvereva EL, Kozlov MV (2006) Top-down effects on population dynamics of Eriocrania miners (Lepidoptera) under pollution impact: does enemy-free space exist? Oikos 115:413-426

Zvereva EL, Kozlov MV, Kruglova OY (2002) Colour polymorphism in relation to population dynamics of the leaf beetle, Chrysomela lapponica. Evol Ecol 16:523-539 